Didaktik : Jurnal IImiah PGSD STKIP Subang,

\title{
EFEKTIVITAS PENERAPAN STRATEGI SQ3R DALAM MEMAHAMI TEKS LAPORAN HASIL OBSERVASI PADA SISWA KELAS X SMK PLUS ULUMUL QURAN KUNIR TAHUN PELAJARAN 2019/2020
}

\author{
Irpan Maulana \\ STKIP Subang \\ irpanstkipsubang@gmail.com
}

\begin{abstract}
The ability of students to read comprehension is relatively low, especially in understanding the reading text of the report of observations, so we need a learning innovation that can improve students' ability to read comprehension through the application of the SQ3R strategy. The formulation of the problem in this study are (1) How is the ability to read text comprehension reports on students' observations? (2) What is the ability to read understanding text reports of students' observations after using the SQ3R strategy? (3) Is the application of the SQ3R learning strategy effective in learning to read the text of the observation report? The purpose of this study is (1) to describe the ability of students to read the understanding of the text of the observation report. (2) describe the ability of students to read the text of the observation report after using SQ3R. (3) describe the effectiveness of the use of SQ3R in learning to read the text of the observation report. This study uses the Pre Experiment research method with the One-Group Pretest-Postest design. The results of the study showed that there was an increase in the ability to read comprehension in the text of the student's observation report. This is indicated by an increase in the average reading comprehension value of 15.98 from the average results before the implementation of the SQ3R learning strategy by 55.83 and after the implementation of the SQ3R strategy by 71.81. So that the SQ3R strategy is effectively applied to the learning of reading comprehension of the observation report text.
\end{abstract}

Keywords: Reading Comprehension Ability, Text Observation Reports, SQ3R Learning Strategies.

\section{ABSTRAK}

Kemampuan siswa dalam membaca pemahaman relatif masih rendah, khususnya dalam memahami bacan teks laporan hasil observasi, sehingga diperlukan suatu inovasi pembelajaran yang dapat meningkatkan kemampuan siswa dalam membaca pemahaman melalui penerapan strategi SQ3R. Rumusan masalah dalam penelitian ini adalah (1) Bagaimana kemampuan membaca pemahaman teks laporan hasil observasi siswa? (2) Bagaimana kemampuan membaca pemahaman teks laporan hasil observasi siswa setelah dengan menggunakan strategi SQ3R? (3) Apakah penerapan strategi pembelajaran SQ3R efektif dalam pembelajaran membaca teks laporan hasil observasi? Tujuan dari penelitian ini adalah (1) mendeskripsikan kemampuan siswa membaca pemahaman teks laporan hasil observasi. (2) mendeskripsikan kemampuan siswa membaca teks laporan hasil observasi setelah menggunakan SQ3R. (3) mendeskripsikan efektivitas penggunaan SQ3R dalam pembelajaran membaca teks laporan hasil observasi. Penelitian ini menggunakan metode penelitian Pre Experiment dengan desain One- 
Didaktik : Jurnal IImiah PGSD STKIP Subang, ISSN Cetak : 2477-5673 ISSN Online : 2614-733X Volume V Nomor 2, Desember 2019

Group Pretest-Postest. Hasil dari penelitian menunjukkan bahwa adanya peningkatan kemampuan membaca pemahaman pada teks laporan hasil observasi siswa. Hal ini ditunjukan dengan adanya peningkatan nilai rata-rata kemampuan membaca pemahaman sebesar 15,98 dari hasil rata-rata sebelum penerapan strategi pembelajaran SQ3R sebesar 55,83 dan sesudah penerapan strategi SQ3R sebesar 71,81 . Sehingga strategi SQ3R efektif diterapkan pada pembelajaran membaca pemahaman teks laporan hasil observasi.

Kata Kunci : Kemampuan Membaca Pemahaman, Teks Laporan Hsil Observasi, Strategi Pembelajaran SQ3R.

\section{A. Pendahuluan}

Membaca merupakan kegiatan yang rutin dilaksanakan dalam kegiatan belajar dan pembelajaran. Meskipun demikian, kegiatan membaca menjadi hal yang kurang digemari terutama bagi siswa. Padahal, kegiatan membaca amatlah penting dalam menopang pembelajaran dikelas.

Data statistik United Nations Educational, Scientific and Cultural Organization (UNESCO) yang dilansir tahun 2012 dalam Kemendikbud (2016) menyebutkan indeks minat baca di Indonesia baru mencapai 0,001 . Artinya, setiap 1.000 penduduk, hanya satu orang yang memiliki minat baca.

Kegiatan membaca yang dilakukan siswa atau siapapun harus melakukannya atas dasar kebutuhan, bukan paksaan. Jika siswa membaca atas dasar kebutuhan, maka ia akan mendapatkan segala informasi yang ia inginkan. Namun sebaliknya, jika siswa membaca atas dasar paksaan, maka informasi yang ia peroleh tidak akan maksimal. Jadi kegiatan membaca adalah suatu kebiasaan yang harus ditanamkan, harus dipupuk, harus dibina, dan harus dikembangkan. Pembinaan tidak hanya terbatas pada penguasaan teknik membaca saja, melainkan pemilihan bahan bacaan.

Di sekolah, pembelajaran membaca perlu difokuskan pada aspek kemampuan memahami bacaan. Oleh sebab itu, siswa perlu dilatih secara intensif untuk memahami teks bacaan. Hal ini berarti bahwa siswa bukan menghafal, melainkan memahami isi bacaan. Peran guru sangat besar pengaruhnya terhadap kemampuan siswa dalam memahami isi bacaan. Guru bahasa Indonesia sebaiknya mengajarkan kepada siswa tentang strategi, metode, dan teknik membaca yang baik sehingga siswa mampu memahami isi bacaan dengan baik. 
Didaktik : Jurnal IImiah PGSD STKIP Subang, ISSN Cetak : 2477-5673 ISSN Online : 2614-733X Volume V Nomor 2, Desember 2019

Sebagai sebuah alternatif untuk mengatasi permasalahan tersebut, guru dapat menerapkan beberapa strategi yang tepat untuk kegiatan pembelajaran membaca pemahaman, salah satunya adalah strategi SQ3R (survey, question, read, recite, review). Strategi SQ3R adalah strategi pemahaman yang membantu siswa berpikir tentang teks yang sedang mereka baca. Strategi SQ3R (survey, question, read, recite, review) mempunyai beberapa keunggulan, di antaranya adalah dapat membantu siswa mendapatkan sesuatu ketika pertama kali mereka membaca teks. Selain itu, strategi SQ3R (survey, question, read, recite, review) dapat membantu guru dalam membimbing siswa bagaimana membaca dan berpikir layaknya para pembaca efektif.

Rumusan masalah dalam penelitian ini adalah (1) Bagaimana kemampuan membaca pemahaman teks laporan hasil observasi siswa? (2) Bagaimana kemampuan membaca pemahaman teks laporan hasil observasi siswa setelah dengan menggunakan strategi SQ3R? (3) Apakah penerapan strategi pembelajaran SQ3R efektif dalam pembelajaran membaca teks laporan hasil observasi?

Tujuan dari penelitian ini adalah (1) mendeskripsikan kemampuan siswa membaca pemahaman teks laporan hasil observasi. (2) mendeskripsikan kemampuan siswa membaca teks laporan hasil observasi setelah menggunakan SQ3R. (3) mendeskripsikan efektivitas penggunaan SQ3R dalam pembelajaran membaca teks laporan hasil observasi.

Kemampuan membaca menjadi hal yang pokok dalam keberlangsungan pembelajaran dikelas. Membaca merupakan proses kognitif yang berupaya untuk mencari dan menemukan informasi melalui media tulis. Membaca tidak hanya melihat deretan huruf, kata, atau kalimat saja, lebih dari itu membaca merupakan kegiatan memahami dan menginterpretasikan pesan yang disampaikan melalui tulisan sehingga mampu dipersepsikan secara mandiri.

Rahim (Dalman, 2014: 6) membaca mencakup pertama, merupakan suatu proses. Maksudnya adalah informasi dari teks pengetahuan yang dimiliki oleh pembaca mempunyai peranan yang utama dalam membentuk makna. Kedua, membaca adalah strategis. Membaca 
Didaktik : Jurnal IImiah PGSD STKIP Subang, ISSN Cetak : 2477-5673 ISSN Online : 2614-733X Volume V Nomor 2, Desember 2019

yang efektif menggunakan berbagai strategi membaca yang sesuai dengan teks dan konteks dalam rangka mengonstruk makna ketika membaca. Ketiga, membaca interaktif. Keterlibatan pembaca dengan teks tergantung pada konteks. Orang yang senang membaca suatu teks yang bermanfaat, akan menemukan beberapa tujuan yang ingin dicapainya, teks yang dibaca seseorang harus mudah dipahami (realible) sehingga terjadi interaksi antara pembaca dan teks.

Menurut Farr (Dalman, 2014:5) mengemukakan "Reading of education" yang artinya membaca merupakan jantung pendidikan. Hal ini berarti bahwa, orang yang sering membaca, pendidikannya akan maju dan ia akan memiliki wawasan yang luas. Tentu saja hasil membacanya itu akan menjadi skema baginya. Skema inilah yang akan menjadi pengetahuan dan pengalaman yang dimiliki. Jadi, semakin sering seseorang membaca, maka semakin besarlah peluang pendidikannya. Hal inilah yang melatar belakangi banyak orang yang mengatakan bahwa membaca sama dengan membuka jendela dunia. Dengan membaca kita dapat mengetahui seisi dunia sehingga pola berpikir kita pun akan berkembang.

Berdasarkan pemaparan para ahli di atas bahwa membaca tidak hanya melihat deretan huruf atau angka yang dituangkan dalam bentuk tulisan, lebih dari itu semua bahwa membaca merupakan proses memahami dan menafsirkan isi atau pesan sebagai upaya manifestasi pengetahuan dan penentu keberhasilan seseorang dalam belajar.

SQ3R pada prinsipnya singkatan dari langkah-langkah dalam mempelajari buku teks atau buku pelajaran. Survey, maksudnya memeriksa atau meneliti atau mengidentifikasi seluruh teks. Question, maksudnya menyusun daftar pertanyaan yang sesuai dengan wacana. Read, maksudnya membaca wacana secara aktif untuk mencapai pertanyaanpertanyaan yang telah tersusun. Recite, maksudnya menghafal semua jawaban atas pertanyaan yang telah tersusun atau ditemukan. Review, maksudnya meninjau ulang seluruh jawaban atas pertanyaan yang telah tersusun pada langkah kedua dan ketiga (Dalman, 2014:189).

Laksono (2007:1-3) SQ3R adalah strategi membaca untuk menemukan ide-ide pokok dan pen- 
Didaktik : Jurnal IImiah PGSD STKIP Subang, ISSN Cetak : 2477-5673 ISSN Online : 2614-733X Volume V Nomor 2, Desember 2019

dukung ide pokok sehingga membantu pembaca dapat mengingat lebih lama. Strategi ini dianggap sebagai strategi membaca yang cukup efektif dan dapat menghasilkan pemahaman yang baik. SQ3R mencakup lima langkah kegiatan secara berurutan, yaitu survey (penelaahan pendahuluan), question (bertanya), read (baca), recite (mengutarakan kembali), review (mengulang kembali).

SQ3R adalah strategi yang efektif dan sistematis untuk membantu pembaca dalam menemukan ide pokok dan pendukung ide, serta menghasilkan pemahaman yang baik. Tujuan utama strategi ini untuk meningkatkan pemahaman atas isi bacaan dan mempertahankan pemahaman tersebut dalam jangka waktu yang lebih panjang.

Proses penerapan metode SQ3R dalam pembelajaran dikelas menurut Syah (2010:218-219) adalah sebagai berikut:

a. Persiapan teknik SQ3R dilakukan dengan langkah-langkah sebagai berikut.

1) Menyiapkan sebuah wacana yang utuh, logis, dan bermakna.

2) Menyiapkan lembar kerja kepada siswa. b. Kegiatan inti dilakukan dengan langkah-langkah sebagai berikut:

1) Survey (penelaah atau pendahuluan). Guru menyiapkan teks laporan hasil observasi mendorong siswa untuk memeriksa atau meneliti secara singkat seluruh struktur teks. Tujuannya, agar siswa mengetahui judul, panjangnya teks, istilah, kata kunci, dan sebagainya. Siswa dianjurkan menyiapkan pensil, kertas, dan alat pembuat ciri (berwarna merah, kuning dan sebagainya) warna untuk menandai bagian-bagian penting yang akan dijadikan pertanyaan.

2) Question (tanya). Guru memberi petunjuk atau contoh kepada siswa untuk menyusun pertanyaan-pertanyaan yang jelas, singkat, dan relevan dengan bagian-bagian teks. Jumlah pertanyaan bergantung pada panjang-pendeknya teks, dan kemampuan siswa dalam memahami teks yang dibaca.

3) Read (baca). Guru menugaskan siswa untuk membaca teks secara aktif dalam rangka mencari jawaban atas pertanyaan-pertanyaan yang telah 
Didaktik : Jurnal IImiah PGSD STKIP Subang, ISSN Cetak : 2477-5673 ISSN Online : 2614-733X Volume V Nomor 2, Desember 2019

tersusun. Dalam hal ini, membaca secara aktif berarti membaca yang difokuskan pada paragraf-paragraf yang diperkirakan mengandung jawaban-jawaban yang relevan dengan pertanyaan.

4) Recite (mengutarakan kembali) Guru menugaskan siswa untuk menyebutkan lagi jawabanjawaban atas pertanyaan yang telah tersusun. Guru melatih siswa untuk tidak melihat atau membuka catatan jawaban.

5) Review (mengulang kembali) Guru menugaskan siswa untuk meninjau ulang seluruh pertanyaan dan jawaban secara singkat.

\section{c. Tindak lanjut}

Setelah langkah awal dan kegiatan inti dilaksanakan, dilakukan tindak lanjut yaitu: memberikan pengayaan berupa pemberian tugas yang sama (dengan bahan yang berbeda) yaitu mengerjakan langkahlangkah SQ3R.

Berdasarkan uraian di atas, yang dimaksud dengan metode SQ3R dalam penelitian ini adalah suatu metode pembelajaran yang sistematik dan bersifat praktik, untuk pembentukan keterampilan membaca secara intensif dan rasional. Implementasi metode ini dengan lima tahapan kegiatan yaitu, memeriksa atau meneliti secara singkat seluruh struktur teks, menyusun pertanyaan-pertanyaan yang jelas, singkat, dan relevan dengan bagian-bagian teks, membaca teks secara aktif dalam rangka mencari jawaban atas pertanyaanpertanyaan yang telah tersusun, menyebutkan kembali jawabanjawaban atas pertanyaan yang telah tersusun tanpa melihat atau membuka catatan, dan meninjau ulang seluruh pertanyaan dan jawaban secara singkat.

\section{B. Metode Penelitian}

Subjek penelitian ini adalah siswa kelas X SMK Plus Ulumul Quran Kunir Kabupaten Subang. Sampel pada penelitian ini adalah siswa kelas X OTKP (Otomatisasi Tata Kelola Perkantoran) yang berjumlah 36 orang. Pemilihan sampel dilakukan dengan teknik Nonprobability Sampling jenis Purposive Sampling yang mana teknik ini dilakukan dengan cara mengambil anggota sampel berdasarkan tujuan tertentu. Mensinegrikan dengan metode penelitian yang diterapkan, maka pengambilan sampel hanya diterapkan kepada satu kelas 
Didaktik : Jurnal IImiah PGSD STKIP Subang, ISSN Cetak : 2477-5673 ISSN Online : 2614-733X Volume V Nomor 2, Desember 2019

saja dari jumlah keseluruhan populasi kelas $\mathrm{X}$ yang terdiri atas dua kelas.

Pada penelitian ini peneliti menerapkan penelitian eksperimen didasarkan pada tujuan penelitian yang ingin dicapai yaitu mendeskripsikan pengaruh (efektivitas) sebuah strategi SQ3R terhadap kemampuan membaca pemahaman siswa.

Berdasarkan hubungan antar variabel dalam penelitian ini, maka penelitian yang diterapkan adalah penelitian kuantitatif. Hal ini sejalan dengan yang telah dijelaskan di paragraf sebelumnya bahwa dalam penelitian ini akan meneliti efektivitas dari sebuah strategi pembelajaran SQ3R terhadap kemampuan membaca pemahaman siswa.

Metode penelitian yang digunakan dalam penelitian ini adalah metode Pre Eksperimen. Peneliti akan menguji efektivitas dari pengaruh strategi pembelajaran SQ3R terhadap kemampuan membaca pemahaman siswa, dengan cara membandingkan kemampuan membaca pemahaman siswa sebelum penerapan strategi pembelajaran SQ3R (pretest) dengan kemampuan membaca pemahaman siswa setelah penerapan strategi pembelajaran SQ3R (posttest). Objek membaca pemahaman yang diterap- kan dalam penelitian ini yaitu membaca pemahaman dari bacaan teks hasil observasi.

Desain penelitian yang digunakan dalam penelitian ini adalah preexperimental designs yaitu bentuk desain one-group pretest-posttest. Pada penerapan desain one-group pretest-posttest ini terdapat penerapan pretest atau tes awal sebelum dilakukan perlakuan atau treatment strategi SQ3R, dari hasil treatment pretest tersebut kemudian dibandingkan dengan hasil dari treatment posttest atau tes yang dilakukan setelah penerapan strategi SQ3R. Hal tersebut dilakukan untuk mengetahui sejauh mana efektivitas dari penerapan strategi SQ3R dalam upaya peningkatan kemampuan membaca pemahaman siswa yang disesuaikan dengan rumusan permasalahan yang telah ditetapkan sebelumnya.

Berdasarkan desaian yang diterapkan, maka penelitian eksperimen ini diterapkan pada siswa terlebih dahulu dengan melakukan pretest atau tes awal $\left(\mathrm{O}_{1}\right)$ yang mana kemudian diberlakukan treatment atau perlakuan dengan menerapkan strategi SQ3R $(X)$ dalam proses pembelajaran membaca pemahaman. 
Didaktik : Jurnal IImiah PGSD STKIP Subang, ISSN Cetak : 2477-5673 ISSN Online : 2614-733X Volume V Nomor 2, Desember 2019

Setelah penerapan treatment strategi SQ3R langkah selanjutnya yaitu siswa diberikan kembali tes atau lebih tepatnya posttest $\left(\mathrm{O}_{2}\right)$ hal ini dilakukan untuk mengetahui efektivitas strategi SQ3R terhadap kemampuan membaca pemahaman siswa. Dari hasil posttest tersebut kemudian dibandingkan dengan hasil pretest yang telah dilakukan dan hasilnya akan memberikan penentuan efektifitas tidaknya strategi SQ3R terhadap kemampuan membaca pemahaman siswa.

\section{Hasil dan Pembahasan}

Hasil penelitian terbagi ke dalam dua kategori tes pemahaman membaca pada materi teks laporan hasil observsi, yaitu hasil pretest dan hasil posttest. Hasil pretest dilakukan sebelum penerapan strategi SQ3R, sedangkan hasil posttest dilakukan setelah pengerapan strategi SQ3R. Dalam soal tes pemahaman yang diujikan terbagi kedalam 20 soal tes pemahaman membaca yang kemudian dibagi lagi kedalam empat sub kategori soal, yaitu soal 1) soal kategori knowledge (pengetahuan) yang terdiri atas delapan soal (nomor soal 1-8), 2) soal kategori comprehension (pemahaman) yang terdiri atas delapan soal (soal nomor 9-16), 3) soal kategori application (penerapan) yang terdiri atas dua soal (soal nomor 17-18), serta 4) soal kategori analysis (analisis) yang teridiri atas dua soal (soal nomor 1920) dengan klasifikasi kriteria skor yang dibuat adalah sebagai berikut.

Tabel 1

Rentang Representasi Skor

\begin{tabular}{lc}
\hline \multicolumn{1}{c}{ Kriteria } & Rentang Skor \\
\hline Sangat Tinggi & $85-100$ \\
\hline Tinggi & $65-80$ \\
\hline Sedang & $45-60$ \\
\hline Rendah & $25-40$ \\
\hline Sangat Rendah & $<25$
\end{tabular}

Kemampuan membaca pemahaman teks laporan hasil observasi pada siswa sebelum penerapan strategi SQ3R masih tergolong rendah. Dibuktikan dengan pengujian tes awal pada siswa yang menghasilkan nilai rata-sebesar 55,83 dengan kategori sedang.

Berdasarkan analisis data yang telah dilakukan, nilai terkecil yang diperoleh pada saat pretest hanya sebesar 35 dengan frekuensi siswa yang memperoleh nilai tersebut sebanyak tiga siswa atau $8 \%$. Kemudian, untuk nilai sedang hanya memperoleh nilai sebesar 60 yang didapatkan oleh satu siswa atau $3 \%$, 
Didaktik : Jurnal IImiah PGSD STKIP Subang, ISSN Cetak : 2477-5673 ISSN Online : 2614-733X Volume V Nomor 2, Desember 2019

sedangkan nilai tertinggi hanya mendapatkan nilai 85 yang didapatkan oleh satu siswa atau $3 \%$. Hasil yang didapatkan dari analisis data pretest siswa, kebanyakan siswa masih kurang pemahaman dalam jenis soal analisis.

Kemampuan membaca pemahaman pada teks laporan hasil observasi setelah diberi penerapan strategi SQ3R kembali diuji melalui sebuah tes yang sama. Berdasarkan hasil pengujian, didapatkan nilai ratarata kemampuan membaca pema-haman siswa mengalami peningkatan sebesar 71,81. Bila dikategorikan dalam rentang represtasi skor yang termasuk pada kategori tinggi.

Kemampuan membaca pemahaman teks hasil observasi disetiap aspek membaca pemahaman, yaitu kategori soal pengetahuan (knowledge), pemahaman (comprehension), penerapan (application), dan analisis (analysis) mengalami peningkatan. Nilai terendah yang didapatkan mengalami peningkatan yang sebelum tidak diberi perlakuan SQ3R, yaitu 35 meningkat menjadi 50 sesudah diberi perlakuan SQ3R. Selanjutnya, nilai sedang mengalami peningkatan dari nilai 60 menjadi nilai 70. Kemudian, nilai tertinggi juga mengalami peningkatan dari nilai 85 menjadi nilai 95 setelah diterapkannya strategi pembelajaran SQ3R. Hal tersebut membuktikan bahwa kemampuan membaca pemahaman siswa sudah lebih baik atau mengalami peningkatan dibandingkan pada saat pretest atau sebelum diberlakukannya penerapan strategi SQ3R.

Berdasarkan hasil penelitian, analisis, dan pembahasan baik pretest maupun posttest dapat dinyatakan bahwa penerapan pembelajaran strategi SQ3R tergolong efektif karena nilai membaca pemahaman siswa mengalami peningkatan. Peningkatan dapat terlihat dari masing-masing jenis soal pemahaman, serta diperkuat dengan peningkatan nilai ratarata secara keseluruhan, yaitu dari 55,83 menjadi 71,81. Peningkatan rata-rata nilai pretest maupun posttest kemampuan membaca pemahaman siswa, yaitu sebesar 15,98. Hal tersebut membuktikan bahwa penerapan strategi pembelajaran SQ3R pada pembelajaran membaca pemahaman siswa, yaitu sangat efektif meningkatkan kemmapuan membaca pemahaman siswa.

Keefektifan tersebut juga didukung dengan hasil analisis data yang diuji melalui uji hipotesis dengan hasil 
Didaktik : Jurnal IImiah PGSD STKIP Subang, ISSN Cetak : 2477-5673 ISSN Online : 2614-733X Volume V Nomor 2, Desember 2019

pengujian nilai signfikansi sebesar 0,00 . Nilai tersebut lebih kecil dari nilai ketetapan signfikansi $(0,05)$. Berdasarkan nilai uji analisis hipotesis tersebut membuktikan bahwa terdapat perbedaan kemampuan membaca pemahaman pada teks hasil observasi antara pretest dengan nilai posttest. Sesuai dengan rumusan data hipotesis yang dibuat dapat dinyatakan bahwa kemampuan membaca pemahaman siswa setelah penerapan strategi SQ3R lebih tinggi dibandingkan sebelum penerapan pembelajaran strategi SQ3R. Dengan demikian, strategi SQ3R terbukti efektif dalam meningkatkan kemampuan membaca pemahaman siswa.

\section{Kesimpulan}

Berdasarkan hasil penelitian dan pembahasan yang telah dijelaskan pada bahasan sebelumnya maka dapat disimpulkan sebagai berikut.

1. Kemampuan membaca pemahaman teks laporan hasil observasi sebelum penerapan strategi SQ3R rata-ratanya sebesar 55,83. Artinya, kemampuan membaca pemahaman teks laporan hasil observasi pada siswa sebelum penerapan strategi SQ3R masih rendah.
2. Kemampuan membaca pemahaman teks laporan hasil observasi pada siswa setelah menerapkan pembelajaran strategi SQ3R sebesar 71,81. Artinya, kemampuan membaca pemahaman teks laporan hasil observasi siswa mengalami peningkatan setelah penerapan strategi SQ3R.

3. Penerapan strategi SQ3R efektif diterapkan pada pembelajaran membaca pemahaman teks laporan hasil observasi. Hal ini dibuktikan dengan adanya peningkatan nilai rata-rata kemampuan membaca pemahaman teks hasil observasi sebesar 15,98 pada siswa setelah diterapkannya strategi pembelajaran SQ3R.

\section{DAFTAR PUSTAKA}

Anitah \& Supriyati. (2008). Strategi Pembelajaran. Jakarta:Universitas Terbuka.

Arikunto, S. (2010). Prosedur Penelitian Suatu Pendekatan Praktik. Jakarta: Rineka Cipta Arikunto, S. (2010). Prosedur Penelitian Suatu Pendekatan Praktik. Jakarta: Rineka Cipta.

Dalman. (2014). Keterampilan Membaca. Jakarta: PT. Raja Grafindo Persada. 
Didaktik : Jurnal IImiah PGSD STKIP Subang, ISSN Cetak : 2477-5673 ISSN Online : 2614-733X

Volume V Nomor 2, Desember 2019

Darmadi. (2010). Metode Penelitian Pendidikan dan Sosial. Bandung: Alfabeta.

Huda, Miftahul. (2013). Model-Model Pengajaran dan Pembelajaran. Yogyakarta: Pustaka Pelajar.

Harsiati, Titik, Dkk. (2017). Bahasa Indonesia SMP/MTS Kelas VII Kementrian Pendidikan dan Kebudayaan. Pusat Kurikulum: Kemendikbud

Indrawan, R dan Yaniawati, P. (2016). Metodologi Penelitian Kuantitatif, Kualitatif, dan Campuran untuk Manajemen, Pembangunan dan Pendidikan. Bandung: PT Refika Aditama.

Kemendikbud. (2016). Survei Pusat Badan Statistika PBS. https://www.pauddikmas.kemdikbu d.go.id/berita/8459.html. Diunduh pada tanggal [19 Mei 2019]

Kosasih, H.E (2014). Jenis-Jenis Teks Analisis Fungsi, Struktur, dan Kaidahnya Serta Langkah Penulisannya. Bandung: Yrama Widya.

Laksono, Kisyani, DKK. 2007. Membaca 2. Jakarta: Universitas Terbuka. Khuzaimatun, Siti.2009. "Upaya Meningkatkan Kemampuan
Membaca Pemahaman dengan Metode SQ3R pada Siswa Kelas X.3 SMA Negeri 1 Sumberlawang". Skripsi SI. Solo: Jurusan Pendidikan Bahasa dan Seni, Fakultas Keguruan dan IImu Pendidikan,UNS.[online]. Tidak diterbitkan. Tersedia: https://core. ac.uk [5 Juli 2019]

Nasution. (2003). Metode Research. Jakarta: PT. Bumi Aksara.

Purwanto. (2008). Metode Penelitian Kuantitatif. Yogyakarta: Pustaka Pelajar.

Rosidi, A. (2016). Pembinaan Minat Baca. Bandung: PT. Remaja Rosdakarya

Rahyubi. (2012). Teori-teori Belajar dan Aplikasi Pembelajaran Motorik. Bandung: Nusa Media.

Randu Gupita, Millatina (2015). Keefektifan Strategi SQ3R (SurveyQuestion-Read-Recite-Review) dalam Memahami Teks Eksplanasi Pada Siswa Kelas VII Negeri 12 Magelang Jawa Tengah.S1 thesis, Universitas Negeri Yogyakarta [online]. Tidak diterbitkan. Tersedia: http:// eprints. uny. ac.id/id/eprint/24072.[1 Juni 2019] 
Samsuddin, AR dan Damianti Vismaia

S. (2015) Metode Penelitian

Pendidikan Bahasa. Bandung: PT. Remaja Rosdakarya Offset

Sanjaya. (2010). Strategi pembelajaran Berorientasi Standar Proses Pendidikan. Jakarta: Prenada Media Group.

Sutedi. (2011). Good Coporate Governance. Jakata: Sinar Grafika. Sugiyono. (2015). Metode Penelitian Kuantitatif, Kualitatif, dan $R \& D$. Bandung: Alfabeta.

Suherman, E. dkk. (2003). Strategi Pembelajaran Matematika Kontemporer. Bandung : JicaImstep Project.

Tarigan, Henry Guntur. (2015). Membaca Sebagai Suatu Keterampilan Berbahasa. Bandung: Angkasa

To, K. (2003). Mengenal Analisis Tes (Edisi ke-2). Bandung: Universitas Pendidikan Indonesia.

Tampubolon, DP. (2015). Kemampuan Membaca Teknik Membaca Efektif dan Efisien. Bandung: Angkasa 